\title{
Representasi Kelas Sosial Mahasiswa Fakultas Kedokteran Gigi (FKG) Universitas Baiturrahmah Padang Melalui Instagram
}

\author{
Rizky Wiradini', Erianjoni Erianjoni ${ }^{2}$ \\ 1,2 Universitas Negeri Padang \\ Email: wiradinirizky@gmail.com, erian_joni@yahoo.com
}

\begin{abstract}
Abstrak
Penelitian ini bertujuan untuk melihat bagaimana Representasi Kelas Sosial Mahasiswa Fakultas Kedokteran Gigi Universitas Baiturrahmah Padang Melalui Instagram. Penelitian ini dianalisis dengan teori representasi yang dikemukakan oleh Serge Moscovici. Teknik pemilihan informan dengan purposive sampling. Penelitian ini menggunakan pendekatan kualitatif tipe studi kasus. Teknik pengumpulan data dilakukan dengan observasi, wawancara dan dokumentasi yang dianalisis dengan menggunakan teknik analisis data dari Miles dan Huberman. Hasil penelitian ini menunjukkan bahwa Proses representasi akan membawa makna menuju konstruksi kelas sosial seseorang. Proses ini juga dapat memproduksi makna baru dan sebaliknya, proses representasi dapat dipandang sebagai proses konsumsi makna. Proses representasi terkait dengan anchoring, yaitu dengan simbol-simbol dan peraturan yang ada dalam masyarakat dan mengantarkan sebuah hal menjadi bermakna. Kelas sosial juga dapat direpresentasikan serta tidak terpisahkan dari anchoring yang ada dalam masyarakat. Sebaliknya, anchoring juga tidak dapat berdiri sendiri melainkan terbentuk dari proses obyektivasi yang ditampakkan melalui foto, video dan instastory mahasiswa FKG Universitas Baiturrahmah.
\end{abstract}

Kata kunci: (Representasi, Kelas sosial, Instagram)

\begin{abstract}
This research aims to look at how the representation of social class students of the Faculty of Dentistry of the University of Baiturrahmah the field Via Instagram. This research analyzed with the theory of representations expressed by Serge Moscovici. The technique of selection of informants by purposive sampling. This research used the qualitative case study-type approach. Engineering data collection done by observation, interview and documentation analyzed using techniques of data analysis from Miles and Huberman. The results of this study indicate that The process of representation will bring meaning towards the construction of an individual's social class. This process can also produce new meaning and vice versa, the process of representation can be seen as a process of consumption significance. Process representations associated with anchoring, i.e. with the symbols and rules that exist in society and deliver a thing becomes meaningless. Social class can also be represented as well as an integral part of anchoring that exist in society. Instead, anchoring also can not stand alone but rather formed from the obyektivasi process showed through photos, videos and instastory Baiturrahmah University of Dentistry Student.
\end{abstract}

Keywords : Representation, Social Class, Instagram 


\section{Pendahuluan}

Media sosial merupakan media di internet yang memungkinkan pengguna merepresentasikan dirinya maupun berinteraksi, bekerja sama, berbagi, berkomunikasi dengan pengguna lain, dan membentuk ikatan sosial secara virtual. Media sosial merupakan media digital tempat realitas sosial terjadi dan ruang-waktu para penggunanya berinteraksi. Nilai-nilai yang ada di masyarakat maupun komunitas juga muncul bisa dalam bentuk yang sama atau berbeda di internet. Namun, pada dasarnya, beberapa akademisi yang meneliti internet melihat bahwa media sosial di internet adalah gambaran apa yang terjadi di dunia nyata (Nasrullah, 2016: 51).

Salah satu survey yang dilakukan oleh situs social on the rocks, sebuah web terkemuka untuk gadget \& technology yang berbasis di Amerika Serikat, menemukan bahwa sebanyak $67 \%$ pengguna instagram merupakan warga dengan usia produktif 18-34 tahun. Pengguna instagram dengan rentang umur 18-34 tahun adalah umur mahasiswa dimana yang dikatakan Hurlock, dalam Hidayatulloh (2014) Usia mahasiswa sebagai dimaklumi, untuk strata 1 (S1) umumnya sekitar 18-24 tahun, mereka berada pada masa remaja akhir dan dewasa awal, atau berada diantara keduanya yakni masa transisi dari masa remaja ke masa dewasa. Mahasiswa menggunakan instagram untuk melihatkan diri mereka pada khalayak banyak dengan menggunakan fitur-fitur instagram. Pada mahasiswa level atas atau mahasiswa yang bisa dikatakan berada pada kelas menengah atas justru mereka juga menggunakan instagram sebagai aplikasi untuk memamerkan apa yang mereka punya atau memberitahukan para pengikutnya bahwa saya punya ini, punya itu, sedang ini, sedang berada disitu, makan di sini dan disitu. Begitulah istilahnya. Terdapat pengguna wanita (55\%) daripada pengguna laki- laki yang jumlahnya sebesar $45 \%$. Hal tersebut kemungkinan dipengaruhi oleh kecenderungan wanita untuk lebih terbuka dalam berbagi kehidupan pribadinya didalam media jejaring sosial, dibandingkan dengan laki-laki yang lebih tertarik pada kebutuhan yang berhubungan dengan karir dan kehidupan sehari-harinya.

Pada Universitas Baiturrahmah khususnya FKG rata-rata mahasiswanya memakai instagram hal ini diketahui dari wawancara singkat dengan beberapa informan dari mahasiswa FKG. Mereka manampakkan simbol-simbol yang mernyatakan mereka adalah kelas menengah atas pada media sosial instagram. Seperti style yang berkelas yaitu memakai brand-brand terkenal seperti Hermes, Channel, Gucci, CK, LV, Dior, Radwah, Ria Miranda, Adidas, Dian Pelangi dan brand-brand terkenal yang lainnya. Dari style ini kita bisa melihat mereka berada di kelas mana, yaitu kelas menengah ke atas. Dalam keseharian mereka, mereka sering menampakkan hal tersebut di dalam media sosial instagram mereka. Dengan postinganpostingan yang menunjukkan kelas mereka. Hal inilah yang menjadi latar belakang penelitian ini, yaitu untuk melihat bagaimana Representasi Kelas Sosial Mahasiswa FKG- Unbrah melalui instagram.

\section{Metode Penelitian}

Penedekatan dalam penelitian ini adalah pendekatan kualitatif, yaitu suatu pendekatan yang menjelaskan realitas sosial yang diteliti secara mendalam. Tipe penelitian yang digunakan adalah studi kasus yaitu menelaah mengenai suatu keadaan masyarakat yang dilihat dari persoalan atau kasus tertentu, baik dalam lembaga, kelompok maupun individu. Teknik pemilihan informan yaitu dengan purposive sampling, dengan jumlah informan 20 orang yang antaranya adalah mahasiswa FKG universitas Baiturrahmah yang memiliki akun 
instagram dan benar-benar berada pada kelas sosial menengah keatas yang dilihat dari postingannya,informan yang dipilih terkhusus pada mahasiswa yang berjenis kelamin perempuan. Karena yang banyak menampilkan kriteria atau simbol-simbol kelas sosial keatas di akun instagram itu adalah perempuan. Jarang sekali ditemukan laki-laki.

Teknik pengumpulan data dilakukan melalui observasi, wawancara mendalam dan studi dokumen. Pengamatan yang dilakukan adalah pada akun instagram milik informan. Kemudian melakukan wawancara mendalam dengan mahasiswa atau informan yang telah ditetapkan.

\section{Hasil}

Paradigma utama merujuk pada dua proses besar pembentukan representasi sosial : obyektivasi (objectification) yang menjelaskan intervensi kelompok-kelompok sosial (norma, nilai, kode/simbol, dll, yang ikut campur sebagai meta-sistem yang mengatur proses kognitif) serta kendala-kendala komunikasi dalam penyeleksian dan pengaturan unsur-unsur representasi di satu pihak, dan pengakaran (anchoring) yang menjelaskan pengintegrasian informasi-informasi baru ke dalam sistem pengetahuan dan pemaknaan yang sudah ada, di lain pihak. Proses itu menjelaskan juga cara elemen-elemen tersebut diperkenalkan kembali, sebagai instrumen operasional, dalam interpretasi terhadap situasi dunia dan dalam interaksi dengan orang lain. Deaux dan Philogene, 2001: 135

Ada tiga dimensi di dalam teori representasi yaitu (informasi, sikap, dan ranah representasi, yang mencakup gambaran, ekspresi nilai-nilai, kepercayaan, dan opini, dll). Dalam hal pembentukan isi yang berhubungan dengan komunikasi sosial yang langsung, 3 faktor (penyebaran dan kesenjangan informasi yang bisa berupa penundaan atau ketidakberfokusan, tekanan dalam inferensi seperti berkesimpulan sendiri bagi penutur, serta kepentingan penutur dan implikasinya pada komunikasi) akan mempengaruhi aspek-aspek kognitif dalam representasi dan membedakan pemikiran awam dalam pola penalarannya, logikanya, dan gayanya.

Pertama, obyektivasi (Objectification) menjelaskan intervensi kelompok-kelompok sosial (norma, nilai, kode/simbol, dll, yang ikut campur sebagai meta-sistem yang mengatur proses kognitif yaitu terlihat pada hasil penelitian mengenai bagaimana representasi kelas sosial pada mahasiswa FKG-Unbrah berdasarkan postingan yang ditampilkan dalam media sosial yaitu instagram milik mereka. Representasi kelas sosial pada mahasiswa FKG-Unbrah berdasarkan postingan yang ditampilkan dalam media sosial yaitu instagram milik mereka. Terdapat pada postingan yang diunggah, yang memperlihatkan rumah, mobil, liburan keluar negeri dan aktivitasnya seperti berbelanja di tempat branded atau dalam kelas sosial disebut dengan kekayaan. Kemudian terdapat postingan tentang kegiatan selama di perkuliahan seperti kegiatan praktek dan lainya di bidang pendidikan.

\section{Informasi dan sikap}

Dalam melihat foto-foto dan postingan lainnya di media sosial instagram, bagaimana foto-foto tersebut mengandung tanda ataupun simbol-simbol yang kebermaknaannya sudah diakui masyarakat sebagai wujud dari informasi mengenai apa yang dipresentasikan. Simbolsimbol tersebut dapat berupa situasi, latar, obyek dan subyek foto. Dengan melihat berbagai simbol atau tanda, proses representasilah yang akan membawa simbol tersebut menjadi suatu makna yang menuju konstruksi kelas sosial individu yang menghendaki suatu postingan. Hal inilah yang membuat foto seringkali digunakan untuk merepresentasikan kelas sosial karena memiliki ruang bagi simbol-simbol yang bermakna. Simbol-simbol tersebut dapat menggambarkan kelas sosial mereka karena kebermaknaannya sudah menjadi regulasi di 
masyarakat yang terbentuk dari berbagai proses sosial. Pada akhirnya, simbol-simbol yang memiliki makna inilah yang menjadi sudut pandang melihat kelas sosial individu.

\section{Ranah}

Ranah yang digunakan untuk mempresentasi kelas sosial mereka dalam instagram adalah feed dan akan muncul di homepage following dan di homepage kita sendiri. Feed adalah keseluruhan foto yang ada pada akun instagram kita. Kita bisa mengatur feed sesuai dengan yang kita ingin kan. Terkadang feed instagram untuk berberapa orang punya tema, misalnya tema gelap, putih, sunset dan lain-lain. Macam-macam feed yang ditemukan pada penelitian ini ada tiga 1) Feed bertema warna 2) Feed bertema fashion 3) Feed bertema travelling dan shopping. Kemudian homepage merupakan halaman utama yang menampilkan (timeline) fotofoto terbaru dari sesama pengguna yang telah diikuti. Cara melihat foto yaitu hanya dengan menggeser layar dari bawah ke atas seperti saat scroll mouse di computer. Kurang lebih 30 foto terbaru dimuat saat pengguna mengakses aplikasi ini, instagram hanya membatasi foto-foto terbaru. Hanya orang-orang yang mengikuti kitalah yang bisa melihat postingan terbaru kita.

Kedua, pengakaran (anchoring) menjelaskan pengintegrasian informasi-informasi baru ke dalam sistem pengetahuan dan pemaknaan yang sudah ada, di lain pihak. Proses itu menjelaskan juga cara elemen-elemen tersebut diperkenalkan kembali, sebagai instrumen operasional, dalam interpretasi terhadap situasi dunia dan dalam interaksi dengan orang lain.

\section{Pandangan diri di media sosial instagram}

Mereka menganggap bahwa postingan yang mereka unggah hanyalah untuk hiburan semata dan untuk berbagi momen, dengan memposting foto, video, dan instastory ke dalam akun instagram milik mereka. Instagram merupakan salah satu ranah untuk mengekspresikan diri agar tidak dikatakan generasi kudate (kurang update) hanya karena tidak memakai instagram dan update seperti orang lain.Tak ada niat atau kesengajaan untuk menampakkan kekayaan maupun kelas dalam postingan pada akun instagram mereka. Postingan yang mereka upload berupa, foto-foto travelling, shopping, OOTD, fashion, dirumah mewah mereka ataupun kegiatan sehari-hari mereka.

\section{Pandangan orang lain terhadap mereka melalui postingan di akun instagram.}

Foto atau postingan yang di upload adalah sarana yang digunakan untuk menyampaikan atau mempresentasikan bahwa mereka berada dikelas menengah atas. Simbol yang tampak adalah seperti kekayaan yang mereka punya, yaitu seperti mobil, rumah mewah, tempat yang mereka kunjungi, barang-barang yang mereka pakai, kemampuan mereka untuk melakukan sesuatu dengan kekayaan yang cukup (objectification). Pendidikan dan pekerjaan yang baik. Dengan kata lain masyarakat memaknai bahwa simbol-simbol tadi adalah simbol- simbol yang berada pada kelas sosial menengah atas. Dan hal inilah yang mengakar pada pikiran masyarakat bahwa dengan simbol-simbol saja masyarakat telah bisa memahami bahwa mahasiswa FKGUnbrah berada pada kelas sosial menengah melalui postingan mereka di instagram (anchoring).

\section{Kesimpulan}

Proses representasi akan membawa makna menuju konstruksi kelas sosial seseorang. Proses ini juga dapat memproduksi makna baru dan sebaliknya, proses representasi dapat dipandang sebagai proses konsumsi makna. Proses representasi terkait dengan anchoring, yaitu dengan simbol-simbol dan peraturan yang ada dalam masyarakat dan mengantarkan sebuah hal menjadi bermakna. Kelas sosial juga dapat direpresentasikan serta tidak terpisahkan dari anchoring yang ada dalam masyarakat. Sebaliknya, anchoring juga tidak 
dapat berdiri sendiri melainkan terbentuk dari proses obyektivasi yang ditampakkan melalui foto, video dan instastory mahasiswa FKG Universitas Baiturrahmah.

Melihat foto-foto dan psotingan lainnya di media sosial instagram, bagaimana fotofoto tersebut mengandung tanda ataupun simbol-simbol yang kebermaknaannya sudah diakui masyarakat. Simbol-simbol tersebut dapat berupa situasi, latar, obyek dan subyek foto. Dengan melihat berbagai simbol atau tanda, proses representasilah yang akan membawa simbol dan makna tersebut menjadi suatu makna yang menuju konstruksi kelas sosial individu maupun kelompok yang menghendaki suatu postingan. Hal inilah yang membuat foto seringkali digunakan untuk merepresentasikan kelas karena memiliki ruang bagi simbol- simbol yang bermakna. Simbol-simbol tersebut dapat menggambarkan kelas sosial mereka karena kebermaknaannya sudah menjadi sebuah proses pengakaran (anchoring) di masyarakat. Pada akhirnya, simbol-simbol yang memiliki makna inilah yang menjadi sudut pandang melihat kelas sosial individu dalam media sosial instagram.

\section{Daftar Pustaka}

Deaux, Dane \& Wrightsman, S. (1993). Social Psychology in the 90's. (2nd).California: Wadsworth Publishing Company, Inc.

Hidayatulloh, Lovita Ivan. (2014). Optimalisasi Fungsi pembimbing Akademik bagi Sukses Studi Mahasiswa (Studi Empirispada Fakultas Agama Islam Universitas Muhammadiyah Surakartaangkatan 2011). Skripsi. Universitas Muhammadiyah Surakarta.

Nasrullah, Rulli. (2015). Media Sosial Perspektif Komunikasi, Budaya dan Sosioteknologi. Bandung: Simbiosa Rekatama Media 